\title{
HUBUNGAN FAKTOR SUHU DENGAN KASUS DEMAM BERDARAH DENGUE (DBD) DI KECAMATAN SAWAHAN SURABAYA
}

\author{
Bella Rosita Fitriana ${ }^{1)}$, Ririh Yudhastuti' ${ }^{2)}$ \\ ${ }^{1,2}$ Departemen Kesehatan Lingkungan, \\ Fakultas Kesehatan Masyarakat, Universitas Airlangga Surabaya \\ Alamat Korespondensi: Bella Rosita Fitriana \\ Email: bellarositata@gmail.com
}

\begin{abstract}
DHF cases is always occured in East Java each year. In 2014, the number of cases reached 14.534 cases with a mortality rate of 146 people. In 2015 reached 9.609 cases with mortality rate of 108 people. Meanwhile in 2016, it increasing high that 20.129 cases occured with a mortality rate of 283 people. BMKG stated that there are extremes climate change can be a risk the increasing high of DHF cases. The purpose of this study was to analyze the relationship of environmental factors and people's behaviour with DHF cases in Putat Jaya Public Health Center Surabaya. The type of this research was analytic, using case-control study design. The research samples were 112 respondents, which obtained by simple random sampling. The data were collected by using a questionnaire and observation. The statistical test used in this study was chi square. The results showed a correlation between the temperature and DHF cases $(p=0.019) ;(O R=0.319)$. The conclusion of this study is temperature factor correlated with DHF cases. Putat Jaya Health Center need to increase the awareness of the citizens and it also need a cooperation with BMKG to provide the information related to temperature changes. When the mosquito is in their good temperature for breeding, citizen need to be aware, they need to keep the enviroment clean, such us doing $3 \mathrm{M}$ Plus
\end{abstract}

Keywords: DHF, temperature, $3 M$ Plus

ABSTRAK
Kasus DBD selalu terjadi di wilayah Jawa Timur setiap tahun. Pada tahun 2014 jumlah kasus mencapai 14.534 kasus dengan angka kematian sebesar 146 jiwa. Pada tahun 2015 mencapai 9.609 kasus dengan angka kematian sebesar 108 jiwa. Pada tahun 2016 terjadi kenaikan yang cukup tinggi yaitu 20.129 kasus dengan angka kematian sebesar 283 jiwa. BMKG menyatakan bahwa adanya perubahan ikilm yang ekstrem berisiko terjadi peningkatan kasus DBD. Tujuan dari penelitian ini adalah menganalisis hubungan faktor lingkungan dan perilaku masyarakat dengan kasus DBD di wilayah kerja Puskesmas Putat Jaya Surabaya. Jenis penelitian adalah analitik dengan menggunakan desain penelitian case control. Sampel penelitian sebanyak 112 responden, diambil secara acak menggunakan simple random sampling. Cara pengumpulan data dengan kuesioner dan pengamatan. Uji statistik yang digunakan adalah uji $\alpha$. Hasil penelitian menunjukkan terdapat hubungan antara suhu dengan kasus DBD $(p=0.019)$; $(O R=0,319)$. Kesimpulan dari penelitian ini adalah faktor suhu berhubungan dengan kasus DBD. Bagi Puskesmas Putat Jaya perlu dilakukan peningkatan kesadaran terhadap warga dan perlu adanya kerja sama dengan BMKG untuk memberikan informasi terkait perubahan suhu. Pada saat nyamuk berada pada suhu yang baik untuk berkembang biak, masyarakat harus menjaga lingkungan agar tetap bersih, seperti melakukan $3 \mathrm{M}$ Plus.

Kata kunci: DBD, suhu, 3M Plus

\section{PENDAHULUAN}

Penyakit menular masih merupakan masalah kesehatan masyarakat di Indonesia. Salah satu penyakitnya yaitu Demam Berdarah Dengue (DBD) yang masih menjadi suatu permasalahan. Penyakit DBD adalah sebuah penyakit yang ditularkan melalui seseorang kepada orang dengan melalui gigitan nyamuk Aedes aegypty dan Aedes albopictus yang disebabkan virus dengue. Virus dengue ditularkan dari orang sakit ke orang sehat melalui gigitan nyamuk Aedes dari sub genus Stegomyia (Gama, et al., 2010).

Kasus DBD selalu terjadi di wilayah Provinsi Jawa Timur setiap tahun. Pada tahun 2014, kasus DBD di Provinsi 
Jawa Timur mencapai 14.534 kasus dengan angka kematian sebesar 146 jiwa. Pada tahun 2015 kasus DBD di Provinsi Jawa Timur mencapai 9.609 kasus dengan angka kematian sebesar 108 jiwa. Pada tahun 2016 terjadi kenaikan yang cukup tinggi yaitu 20.129 kasus dengan angka kematian sebesar 283 jiwa (Dinas Kesehatan Provinsi Jawa Timur, 2016).

Data dari Profil Kesehatan Dinkes

kota Surabaya bahwa Puskesmas Putat Jaya tahun 2014 merupakan puskesmas tertinggi kedua di Surabaya dengan jumlah kasus DBD mencapai total 35 kasus. Pada tahun 2015, jumlah pasien DBD di Puskesmas Putat Jaya menurun sebanyak 10 kasus dan Puskesmas Manukan Kulon menduduk posisi tertinggi sebanyak 47 kasus. Pada tahun 2016 di wilayah kerja Puskesmas Putat Jaya sebanyak 17 kasus.

Faktor iklim memengaruhi terjadinya kasus DBD antara lain ialah suhu, curah hujan, dan kelembapan. Pada suhu tinggi sekitar $25-27^{\circ} \mathrm{C}$ perkembangbiakan nyamuk akan meningkat mengakibatkan kasus DBD akan meningkat. Curah hujan yang tinggi akan mengakibatkan volume genangan air semakin banyak sehingga dapat menjadi tempat perindukan nyamuk Aedes. Pada kelembapan tinggi nyamuk Aedes tidak dapat menularkan virus dengue (Fitriana, 2017). Siklus hidup nyamuk itu sendiri juga dipengaruhi oleh tersedianya air atau genangan sebagai media berkembang biak dari telur menjadi nyamuk dewasa karena aktivitas sehari-hari nyamuk memerlukan suhu yang cukup tinggi dan didukung oleh udara yang lembab. Jumlah nyamuk jantan dan betina yang menetas dari sekelompok telur pada umumnya sama banyak. Nyamuk betina umurnya lebih panjang dari nyamuk jantan dan perlu menghisap darah untuk pertumbuhan telurnya. Waktu menggigit lebih banyak pada siang hari dari pada malam hari. Umur dan kehidupan nyamuk dipengaruhi oleh iklim, kelembapan udara, suhu udara, curah hujan, cahaya, dan angin. Suhu optimum untuk perkembangbiakan nyamuk adalah $25-27^{\circ} \mathrm{C}$. Pada kelembapan 60\% Aedes aegypty tidak dapat menularkan virus dengue, karena nyamuk ini akan terlebih dulu mati sebelum virus dengue sampai di kelenjar liurnya. Virus dengue membutuhkan waktu 8-11 hari untuk memperbanyak diri dalam tubuh nyamuk Aedes aegypty hingga cukup untuk menyebabkan infeksi pada manusia (Oktivani, 2011).

Kasus DBD meningkat karena masih banyaknya tempat perindukan nyamuk yang berupa bak mandi, ember, gentong, Tempat Penampugan Air (TPA) yang bukan untuk keperluan sehari-hari misalnya vas bunga, ban bekas, tempat sampat, tempat minum burung, serta tempat penampungan air alamiah yaitu lubang pohon, pelepah daun keladi, lubang batu, dan lain-lain (Depkes, 2005). Penyakit berbasis lingkungan berhubungan dengan sanitasi. Apabila masyarakat mempunyai kebiasaan buruk dan tidak menjaga kebersihkan lingkungan rumah maka akan berisiko terkena penyakit DBD. Faktor lain yang memengaruhi kasus DBD di Indonesia antara lain faktor hospes, faktor lingkungan (environtment), dan respon imun. Faktor lingkungan yaitu kondisi geografis (ketinggian dari permukaan laut, curah hujan, kelembapan, musim), kondisi demografis (kepadatan hunian rumah, mobilitas penduduk, perilaku buruk yang dapat menimbulkan kasus DBD, adat istiadat, kebiasaan, sosial ekonomi penduduk, jenis, dan kepadatan nyamuk sebagai vektor penular penyakit). Faktor agent yaitu virus dengue yang hingga saat ini diketahui ada 4 jenis seroptipe virus dengue yaitu dengue 1,2,3,4 (Soegijanto, 2006).

Faktor perilaku juga berperan dalam penularan DBD. Perilaku ini berupa tindakan yang dapat memicu terjadinya kasus DBD antara lain adalah kebiasaan dalam kehidupan sehari-hari. Sesuai dengan hasil analisis sebuah penelitian menunjukkan terdapat hubungan antara kebiasaan memakai obat nyamuk di siang hari dengan kasus DBD (Sitio, 2008; 
Winasih, 2013). Berbeda dengan penelitian lain bahwa tidak ada hubungan antara kebiasaan memakai obat nyamuk dengan kasus DBD dan kebiasaan pemakaian kelambu pada saat tidur juga tidak ada hubungan dengan kasus DBD yang dilakukan di daerah endemis maupun sporadis (Mardiana, 2013; Muchlis, et al., 2011). Variabel yang memiliki hubungan dengan kasus DBD di daerah endemis dan sporadis adalah kebiasaan membersihkan TPA minimal sekali dalam seminggu. Penelitian ini menunjukkan bahwa di daerah endemis dan sporadis DBD membersihkan kontainer air dan menggunakan kelambu saat tidur dapat mencegah gigitan nyamuk sehingga penyakit DBD dapat dicegah. Kebiasaan dalam kehidupan sehari-hari tersebut perlu diperhatikan sebagai upaya pencegahan terhadap DBD adalah salah satu cara untuk mengendalikan kasus DBD (Gyawali, et al., 2015; Suwanbamrung, 2013).

\section{METODE PENELITIAN}

Jenis penelitian ini adalah penelitian observasional analitik dimana peneliti hanya melakukan pengamatan tanpa memberikan perlakuan terhadap subyek penelitian dengan menganalisa hubungan antara variabel. Desain penelitian yang digunakan adalah studi case control dengan metode survei dan wawancara. Desain studi case control adalah rancangan studi epidemiologi yang mempelajari hubungan antara paparan dan penyakit dengan cara membandingkan kelompok kasus dengan kelompok kontrol berdasarkan status paparannya.

Populasi pada penelitian ini adalah seluruh masyarakat yang tinggal di wilayah kerja Puskesmas Putat Jaya Kecamatan Sawahan Surabaya pada tahun 2014-2016 yang menderita DBD maupun tidak menderita DBD. Pemilihan Puskesmas Putat Jaya dikarenakan angka kasus DBD Puskemas Putat Jaya tertinggi dari 4 Puskesmas lain yang berada di Kecamatan Sawahan Surabaya. Total populasi penderita DBD pada tahun 2014-2016 sebanyak 116 kasus. Besar sampel pada case control dengan perbandingan kasus dan kontrol 1:1 dalam penelitian ini dihitung berdasarkan rumus Lemeshow sebagai berikut:

$$
\begin{aligned}
& \mathrm{n}=\left(\frac{z_{1-\frac{m}{2}} \sqrt{2 P_{2}\left(1-P_{2}\right)}+z_{1-\beta} \sqrt{P_{1}\left(1-P_{1}\right)+P_{2}(1-)}}{\left(P_{1}-P_{2}\right)^{2}}\right)^{2} \\
& \mathrm{n}=\left(\frac{1,96 \sqrt{(2 x 0.5)(0,5)}+1,28 \sqrt{0,795 \times 0,205+0,15 x 0,5}}{0,295}\right)^{2} \\
& n=56
\end{aligned}
$$

Besar sampel yang didapat dari perhitungan sebesar 56 sampel. Sehingga jumlah sampel diambil dengan perbandingan antara sampel dan kontrol adalah 1:1. Besar sampel kasus 56 orang menderita DBD dan sampel kontrol 56 orang tidak menderita DBD. Total sampel keseluruhan dalam penelitian ini adalah sebanyak 112 orang dan $\alpha$. Tujuan dari penelitian ini adalah menganalisis hubungan faktor lingkungan yang meliputi suhu, kelembapan, curah hujan, dan perilaku masyarakat dengan tingkat endemisitas kasus DBD di wilayah kerja Puskesmas Putat Jaya Kecamatan Sawahan Surabaya.

Penelitian ini dilakukan pada bulan Juli-Agustus 2017. Lokasi penelitian adalah wilayah kerja Puskesmas Putat Jaya Surabaya. Variabel terikat pada penelitian adalah kasus DBD. Variabel bebas pada penelitian ini adalah faktor lingkungan yang meliputi suhu, kelembapan, curah hujan, dan perilaku masyarakat terkait $3 \mathrm{M}$ plus yang meliputi menguras penampungan air, menutup penampungan air, mengubur barang bekas, penggunaan kelambu berinsektisida, penambahan ikan di bak mandi, menaburkan bubuk abate di penampungan air, penggunaan obat nyamuk, menggantung pakaian kotor, dan pemasangan kawat kasa pada ventilasi rumah.

Metode pengambilan sampel pada penelitian ini dilakukan secara acak menggunakan teknik simple random sampling karena populasi relatif homogen. 
Prosedur acak dilakukan dengan metode lotre technique. Cara pengumpulan data dengan kuesioner dan pengamatan. Uji statistik yang digunakan adalah uji chi square. Analisis bivariat digunakan mengetahui hubungan antara variabel bebas yaitu suhu, kelembapan, curah hujan, dan perilaku dengan variabel tergantung kasus DBD. Penelitian ini telah memperoleh keterangan lolos kaji etik dari Komisi Etik FKM No : 165-KEPK.

\section{HASIL}

\section{Suhu}

Tabel 1. Suhu di wilayah Kerja Puskesmas Putat Jaya Tahun 2014-2016

\begin{tabular}{lccc}
\hline \multirow{3}{*}{ Bulan } & \multicolumn{3}{c}{ Tahun } \\
\cline { 2 - 4 } & $\mathbf{2 0 1 4}$ & $\mathbf{2 0 1 5}$ & $\mathbf{2 0 1 6}$ \\
\cline { 2 - 4 } Rata-Rata $\left({ }^{\mathbf{O}} \mathbf{C}\right)$ \\
\hline Januari & 28,0 & 28,4 & 28,4 \\
\hline Februari & 27,8 & 28,2 & 28,2 \\
\hline Maret & 29,0 & 28,5 & 28,5 \\
\hline April & 29,1 & 28,5 & 28,5 \\
\hline Mei & 30,0 & 29,2 & 29,2 \\
\hline Juni & 29,7 & 29,2 & 29,2 \\
\hline Juli & 29,0 & 28,4 & 28,4 \\
\hline Agustus & 28,7 & 28,3 & 28,3 \\
\hline September & 29,0 & 28,9 & 28,9 \\
\hline Oktober & 29,0 & 30,0 & 30,0 \\
\hline November & 30,3 & 31,3 & 31,9 \\
\hline Desember & 30,5 & 31,4 & 31,4 \\
\hline
\end{tabular}

Tabel 2. Kategori Suhu berdasarkan Frekuensi Kelompok Kasus dan Kontrol

\begin{tabular}{lllll}
\hline \multicolumn{1}{c}{ Kategori } & \multicolumn{2}{c}{ Kasus } & \multicolumn{2}{c}{ Kontrol } \\
\cline { 2 - 5 } \multicolumn{1}{c}{ Suhu } & $\mathrm{n}$ & $\%$ & $\mathrm{n}$ & $\%$ \\
\hline $\begin{array}{l}\text { Baik } \\
\left(25{ }^{\circ} \mathrm{C}-28{ }^{\circ} \mathrm{C}\right)\end{array}$ & 35 & 62.5 & 47 & 83,9 \\
\hline $\begin{array}{l}\text { Tidak Baik } \\
\left(<25{ }^{\circ} \mathrm{C} \text { dan }\right.\end{array}$ & 21 & 37,5 & 9 & 16,1 \\
$\left.>28{ }^{\circ} \mathrm{C}\right)$ & & & & \\
\hline Total & 56 & 100,0 & 56 & 100,0 \\
\hline
\end{tabular}

Berdasarkan Tabel 1. rata-rata suhu setiap bulannya cenderung sama. Suhu di wilayah kerja Puskesmas Putat Jaya selama tahun 2014-2016 memiliki nilai rata-rata $29,2{ }^{\circ} \mathrm{C}$. Suhu maksimal dari tahun 20142016 adalah $31,9{ }^{\circ} \mathrm{C}$ dan suhu minimal adalah $27,8{ }^{\circ} \mathrm{C}$. Kategori suhu yang dapat memengaruhi perkembangan nyamuk Aedes dibedakan menjadi 2 yaitu baik ( 25 ${ }^{\circ} \mathrm{C}-28{ }^{\circ} \mathrm{C}$ ) dan tidak baik (lebih besar $25^{\circ} \mathrm{C}$ dan kurang dari $28{ }^{\circ} \mathrm{C}$ ) (Sugito, 1989). Berdasarkan Tabel 2. kategori suhu bahwa yang tertinggi untuk kelompok kasus dan kontrol adalah kategori baik.

\section{Curah Hujan}

Tabel 3. Curah Hujan di wilayah Kerja Puskesmas Putat Jaya Tahun 2014-2016.

\begin{tabular}{|c|c|c|c|}
\hline \multirow{3}{*}{ Bulan } & \multicolumn{3}{|c|}{ Tahun } \\
\hline & 2014 & 2015 & 2016 \\
\hline & \multicolumn{3}{|c|}{ Rata-Rata (mm) } \\
\hline Januari & 272,1 & 436,6 & 284,1 \\
\hline Februari & 335,6 & 293,5 & 409,3 \\
\hline Maret & 186,0 & 243,8 & 163,1 \\
\hline April & 245,9 & 133,0 & 129,6 \\
\hline Mei & 54,8 & 109,7 & 358,8 \\
\hline Juni & 47,7 & 0,7 & 126,8 \\
\hline Juli & 4,0 & 0,0 & 90,1 \\
\hline Agustus & 4,8 & 0,0 & 38,2 \\
\hline September & 0,0 & 0,0 & 102,0 \\
\hline Oktober & 0,4 & 0,0 & 161,5 \\
\hline November & 69,0 & 130,2 & 117,9 \\
\hline Desember & 284,7 & 184,8 & 358,8 \\
\hline
\end{tabular}

Berdasarkan Tabel 3. menyatakan bahwa tahun 2014 curah hujan tertinggi adalah 335,6 mm. Pada tahun 2015 sebesar 436,6 mm. Pada tahun 2016 curah hujan tertinggi sebesar 409,3 mm. Kategori curah hujan dengan intensitas frekuensi wilayah Indonesia dibedakan menjadi 4 yaitu ringan, sedang, lebat dan sangat lebat (BMKG, 2010). Tabel 4 menyatakan 
bahwa kategori curah hujan tertinggi adalah kategori lebat dengan persentase kelompok kasus sebesar 85,7\% dan kelompok kontrol sebesar 71,4\%.

Tabel 4. Kategori Curah Hujan berdasarkan Frekuensi Kelompok Kasus dan Kontrol

\begin{tabular}{lcccc}
\hline \multicolumn{1}{c}{$\begin{array}{c}\text { Kategori } \\
\text { Curah } \\
\text { Hujan }\end{array}$} & \multicolumn{2}{c}{ Kasus } & \multicolumn{2}{c}{ Kontrol } \\
\cline { 2 - 5 } & $\mathbf{N}$ & $\%$ & $\mathbf{n}$ & $\mathbf{\%}$ \\
\hline $\begin{array}{l}\text { Ringan (5- } \\
\text { 20mm) }\end{array}$ & 8 & 14,3 & 16 & 28,6 \\
\hline $\begin{array}{l}\text { Lebat (50- } \\
100 \mathrm{~mm})\end{array}$ & 48 & 85,7 & 40 & 71,4 \\
\hline Total & 56 & 100,0 & 56 & 100,0 \\
\hline
\end{tabular}

\section{Kelembapan}

Gambaran kondisi kelembapan di wilayah kerja Puskesmas Putat Jaya selama tahun 2014-2016 sebagai berikut:

Tabel 5. Kelembapan di wilayah Kerja Puskesmas Putat Jaya Tahun 2014-2016

\begin{tabular}{lccc}
\hline \multirow{2}{*}{ Bulan } & \multicolumn{3}{c}{ Tahun } \\
\cline { 2 - 4 } & $\mathbf{2 0 1 4}$ & $\mathbf{2 0 1 5}$ & 2016 \\
\cline { 2 - 4 } Januari & 90 & 90 & 90 \\
\hline Februari & 89 & 90 & 91 \\
\hline Maret & 90 & 90 & 77 \\
\hline April & 78 & 78 & 81 \\
\hline Mei & 87 & 87 & 78 \\
\hline Juni & 89 & 89 & 80 \\
\hline Juli & 71 & 71 & 78 \\
\hline Agustus & 68 & 68 & 73 \\
\hline September & 64 & 64 & 74 \\
\hline Oktober & 62 & 82 & 80 \\
\hline November & 84 & 83 & 82 \\
\hline Desember & 88 & 88 & 80 \\
\hline
\end{tabular}

Berdasarkan Tabel 5. menyatakan bahwa kelembapan di wilayah kerja Puskesmas Putat Jaya selama tahun 2014 2016 berada pada rentang rata-rata antara $62 \%$ - 91\%. Kelembapan mininum terjadi pada bulan Oktober 2014 sebesar 62\% dan kelembapan maksimum terjadi pada bulan Februari 2016 sebesar 91\%.

Kategori kelembapan yang dapat memengaruhi perkembangan nyamuk Aedes dibedakan menjadi 2 yaitu baik (70$89 \%$ ) dan tidak baik (kurang dari 70\% dan lebih besar 89\%) (Jumar, 2000). Tabel 6 . kelembapan di wilayah kerja Pusksesmas Putat Jaya menunjukkan tertinggi adalah kategori baik (60-89\%) dengan persentase kelompok kasus sebesar $85,7 \%$ dan kelompok kontrol sebesar $82,1 \%$.

Tabel 6. Kategori Kelembapan berdasarkan Frekuensi Kelompok Kasus dan Kontrol

\begin{tabular}{lcccc}
\hline \multicolumn{1}{c}{$\begin{array}{c}\text { Kategori } \\
\text { Kelembapan }\end{array}$} & \multicolumn{2}{c}{ Kasus } & \multicolumn{2}{c}{ Kontrol } \\
\cline { 2 - 5 } & n & $\%$ & n & $\%$ \\
\hline $\begin{array}{l}\text { Baik (70- } \\
89 \%)\end{array}$ & 48 & 85,7 & 46 & 82,1 \\
\hline $\begin{array}{l}\text { Tidak Baik } \\
(<70 \% \text { dan } \\
>89 \%)\end{array}$ & 8 & 14,3 & 10 & 17,9 \\
\hline \multicolumn{1}{c}{ Total } & 56 & 100,0 & 56 & 100,0 \\
\hline
\end{tabular}

\section{Perilaku Masyarakat}

Penilaian skor perilaku masyarakat yang dilakukan di wilayah kerja Puskesmas Putat Jaya dengan menggunakan 2 kategori antara lain adalah kurang untuk nilai 1-13 dan baik untuk nilai 14-26. Berdasarkan Tabel 7 gambaran skor perilaku masyarakat di wilayah kerja Puskesmas Putat Jaya bahwa kategori skor nilai tertinggi adalah kategori kurang dengan persentase kelompok kasus sebesar $78,6 \%$ dan kelompok kontrol sebesar $89,3 \%$. 
Tabel 7. Gambaran Skor Perilaku Masyarakat di wilayah Kerja Puskesmas Putat Jaya sebagai berikut:

\begin{tabular}{lcccc}
\hline \multirow{2}{*}{$\begin{array}{c}\text { Skor } \\
\text { Nilai }\end{array}$} & \multicolumn{2}{c}{ Kasus } & \multicolumn{2}{c}{ Kontrol } \\
\cline { 2 - 5 } & $\mathbf{n}$ & $\%$ & $\mathbf{n}$ & $\boldsymbol{\%}$ \\
\hline $\begin{array}{l}\text { Kurang } \\
(1-13)\end{array}$ & 44 & 78,6 & 50 & 89,3 \\
\hline $\begin{array}{l}\text { Baik (14- } \\
\text { 26) }\end{array}$ & 12 & 21,4 & 6 & 10,7 \\
\hline \multicolumn{1}{c}{ Total } & 56 & 100,0 & 56 & 100,0
\end{tabular}

\section{Kasus DBD di wilayah Kerja Puskesmas Putat Jaya Tahun 2014-2016}

Tabel 8. Jumlah Penderita DBD di wilayah Kerja Puskesmas Putat Jaya Tahun 2014-2016

\begin{tabular}{lrrrrrr}
\hline & \multicolumn{6}{c}{ Tahun } \\
\cline { 2 - 7 } Bulan & $\mathbf{2 0 1 4}$ & $\mathbf{2 0 1 5}$ & $\mathbf{2 0 1 6}$ \\
\cline { 2 - 7 } & \multicolumn{6}{c}{ Kondisi } \\
\cline { 2 - 7 } Januari & 4 & 0 & 6 & 0 & 4 & 0 \\
\hline Februari & 0 & 0 & 8 & 0 & 7 & 0 \\
\hline Maret & 7 & 0 & 5 & 0 & 4 & 1 \\
\hline April & 2 & 1 & 7 & 1 & 6 & 0 \\
\hline Mei & 5 & 0 & 4 & 0 & 3 & 0 \\
\hline Juni & 2 & 0 & 5 & 0 & 4 & 0 \\
\hline Juli & 1 & 0 & 3 & 0 & 2 & 0 \\
\hline Agustus & 3 & 0 & 2 & 0 & 3 & 0 \\
\hline September & 3 & 0 & 1 & 0 & 4 & 0 \\
\hline Oktober & 0 & 0 & 0 & 0 & 0 & 0 \\
\hline November & 3 & 0 & 0 & 0 & 0 & 0 \\
\hline Desember & 3 & 0 & 0 & 0 & 2 & 0 \\
\hline & 33 & 1 & 41 & 1 & 39 & 1 \\
\hline Total & 34 & & 42 & & 40 \\
Kasus & & & & & &
\end{tabular}

Keterangan: $\mathrm{H}=$ Hidup, $\mathrm{M}=$ Meninggal
Berdasarkan Tabel 8. jumlah penderita DBD di wilayah kerja Puskesmas Putat Jaya Surabaya mengalami peningkatan pada tahun 2014 dan 2015 . Namun pada tahun 2016 mengalami penurunan sebanyak 2 kasus dari tahun sebelumnya. Jumlah kasus penderita DBD yang meninggal dunia dari tahun 20142016 sebanyak 1 kasus setiap tahunnya.

\section{Analisis Bivariat}

Tabel 9. Hubungan Kondisi Iklim dan Perilaku Masyarakat dengan Kasus DBD

\begin{tabular}{lcr}
\hline Variabel & $\begin{array}{c}\text { Nilai Chi } \\
\text { Square } \\
\text { Kasus DBD } \\
(\boldsymbol{p} \text {-value })\end{array}$ & OR \\
\hline Suhu & 0,019 & 0,319 \\
\hline Curah Hujan & 0,107 & - \\
\hline Kelembapan & 0,797 & - \\
\hline $\begin{array}{l}\text { Perilaku } \\
\text { Masyarakat }\end{array}$ & 0,198 & - \\
\hline
\end{tabular}

Analisis bivariat dilakukan dengan menggunakan uji chi square dengan tingkat kepercayaan (taraf signifikansi) yang dipakai $0,05(\alpha=5 \%)$, sehingga jika $p$-value kurang dari 0,05 maka hasil perhitungan statistik akan bermakna (ada hubungan), jika $p$-value lebih dari 0,05 maka hasil perhitungan statistik tidak bermakna (tidak ada hubungan). Tabel 9 memperlihatkan dari 4 variabel indepent yang dilakukan uji bivariate. Adanya hubungan kasus DBD dan faktor suhu.

\section{PEMBAHASAN}

Kepadatan penduduk yang semakin padat dalam suatu wilayah atau penghuni rumah maka akan mengakibatkan lebih mudah dan cepat terjadi penularan penyakit. Mobilitas penduduk yang semakin tinggi maka penularan dari satu ke 
tempat lain juga semakin tinggi. Karena penularan virus dengue dapat cepat menular apabila tempat tersebut termasuk wilayah endemis terjadinya kasus DBD. Kualitas perumahan yang baik seperti jarak antara rumah dengan rumah yang lain, pencahayaan, bentuk rumah, bahan bangunan akan memengaruhi penularan. Bila di suatu rumah terdapat nyamuk penularnya maka akan menularkan penyakit pada orang yang tinggal di dalam rumah tersebut atau di rumah sekitarnya yang berada dalam jarak terbang nyamuk dan kepada orang yang berkunjung ke rumah tersebut (Dirjen PPM PLP, 2002).

Tingkat pendidikan masyarakat akan memengaruhi cara berfikir dalam penerimaan informasi penyuluhan dan cara pemberantasan penyakit DBD. Apabila tingkat pendidikan masyarakat rendah akan memengaruhi cara berfikir dalam mencegah penyakit DBD karena pengetahuan yang mereka miliki sangat kurang. Penghasilan setiap keluarga akan berpengaruh pada kunjungan berobat ke pelayanan kesehatan. Semakin rendah tingkat pendapatan keluarga maka semakin rendah pula kunjungan berobat ke pelayanan kesehatan sebaliknya semakin tinggi tingkat pendapatan keluarga. Mata pencaharian juga memengaruhi penghasilan keluarga. Apabila mata pencaharian suatu kelauarga tergolong rendah maka pendapatan yang diperoleh suatu keluarga tersebut rendah sehingga akan memengaruhi kunjungan berobat ke pelayanan kesehatan (Dirjen PPM PLP, 2002).

Apabila seseorang memiliki kebiasaan hidup bersih sehat maka akan cepat tanggap dalam masalah untuk mengurangi risiko penularan penyakit. Sebaliknya apabila seseorang memiliki kebiasaan hidup tidak sehat maka akan berisiko terjadi penularan penyakit. Setiap golongan umur memiliki tingkat risiko dan dapat memengaruhi terjadinya penularan penyakit. Golongan umur kurang dari dari 15 tahun mempunyai peluang lebih besr untuk terjangkit DBD (Dirjen PPM PLP, 2002).

\section{Suhu}

Uji Chi Square antara variabel suhu dengan kasus DBD menunjukkan bahwa adanya hubungan dinatara kedua variabel tersebut. Hal ini menunjukkan bahwa peningkatan suhu akan diikuti dengan peningkatan kasus DBD di wilayah kerja Puskesmas Putat Jaya (Fitriana, 2017).

Suhu adalah parameter lingkungan yang penting dalam meningkatkan perkembangbiakan vektor, siklus gonotropik nyamuk, tingkat gigitan, memperpendek periode inkubasi patogen dan memperpanjang umur nyamuk dewasa. Selain itu, suhu yang lebih tinggi juga meningkatkan tingkat perkembangan larva. Pada nyamuk dewasa, suhu yang lebih tinggi dapat meningkatkan tingkat gigitan nyamuk (biting rate) dan mengurangi waktu yang dibutuhkan virus untuk bereplikasi dalam tubuh nyamuk, yang dikenal sebagai masa inkubasi ekstrinsik virus dengue. Masa inkubasi ekstrinsik virus dalam tubuh nyamuk yang lebih cepat diimbangi dengan tingkat gigitan nyamuk menjadi lebih sering akan mengakibatkan risiko penularan DBD semakin meningkat pula (Gama, et al., 2013).

Suhu di wilayah kerja Puskesmas Putat Jaya selama tahun 2014-2016 ratarata adalah $29,2{ }^{\circ} \mathrm{C}$ dengan rentang suhu berkisar pada $27,8{ }^{\circ} \mathrm{C}-31,9{ }^{\circ} \mathrm{C}$. Suhu tersebut merupakan suhu yang cukup optimum untuk perkembangbiakan nyamuk. Suhu optimum untuk nyamuk berada pada rentang $25^{\circ} \mathrm{C}-27^{\circ} \mathrm{C}$. Selain itu pada rentang suhu $20^{\circ} \mathrm{C}-30^{\circ} \mathrm{C}$ merupakan suhu ideal untuk kelangsungan hidup nyamuk pada semua tahapan siklusnya. Masa inkubasi ekstrinsik virus dalam tubuh nyamuk berkurang dari 9 hari pada suhu $26^{\circ} \mathrm{C}$ dan $28^{\circ} \mathrm{C}$ menjadi 5 hari pada suhu $30^{\circ} \mathrm{C}$. Siklus resproduksi nyamuk betina juga dipegaruhi oleh suhu lingkungan yang mana pada suhu kurang dari $20^{\circ} \mathrm{C}$ fertilisasi nyamuk betina berkurang. 
Aktivitas menggigit nyamuk betina juga dipengaruhi oleh suhu lingkungan. Aktivitas menggigit nyamuk betina yang tinggi akan meningkatkan penyebaran penyakit DBD (Morin, et al., 2013).

\section{Curah Hujan}

curah $\begin{gathered}\text { Uji Chi Square antara variabel } \\ \text { hujan dengan kasus DBD }\end{gathered}$ menunjukkan bahwa tidak adanya hubungan diantara kedua variabel tersebut. Hal ini menunjukkan bahwa peningkatan curah hujan tidak diikuti dengan peningkatan kasus DBD. Karena tidak adanya hubungan kedua variabel tersebut (Fitriana, 2017).

Curah hujan diindikasi memegang peranan penting dalam penularan penyakit DBD. Curah hujan dapat berhubungan dengan kasus DBD dengan dua cara yaitu meningkatkan suhu dan kelembapan udara serta menambah tempat perkembangbiakan atau breeding place nyamuk Aedes aegypti. Semakin banyak breeding place maka nyamuk Aedes aegypti akan menempatkan telurnya. Curah hujan yang tinggi dalam waktu yang lama dapat menyebabkan banjir sehingga menghilangkan tempat perindukan nyamuk Aedes aegypti yang biasanya hidup di air bersih. Hal ini mengakibatkan jumlah perindukan nyamuk akan berkurang sehingga populasi nyamuk akan berkurang. Pada musim kemarau, populasi nyamuk juga dapat bertambah jika masyarakat menyimpan air dalam tempat penyimpanan air yang akan menjadi breeding place nyamuk (Ibara, et al., 2013). Jika curah hujan kecil dan dalam waktu yang lama dapat menambah tempat perindukan nyamuk dan meningkatkan populasi nyamuk (Dini, et al., 2010).

Menurut Ibara, et al. (2013), hubungan iklim dengan kasus DBD dapat terjadi pada variabel curah hujan atau suhu bahkan tidak ada hubungan antara kedua variabel tersebut. Variasi ini bisa disebabkan oleh faktor lain seperti praktik penyimpanan air, pengetahuan dan risiko persepsi masyarakat, dan kondisi perumahan.

\section{Kelembapan}

Uji Chi Square antara variabel kelembapan dengan kasus DBD menunjukkan bahwa tidak adanya hubungan dinatara kedua variabel tersebut. Tidak adanya hubungan antara kelembapan dengan kasus DBD. Hal ini menunjukkan bahwa peningkatan kelembapan tidak akan diikuti dengan peningkatan kejadian penyakit DBD di wilayah kerja Puskesmas Putat Jaya (Fitriana, 2017).

Kelembapan di wilayah kerja Puskesmas Putat Jaya tahun 2014-2016 berada pada rentang 62\%-91\% dengan nilai rata-rata sebesar $81 \%$. Kelembapan tidak berhubungan dengan kasus DBD. Akan tetapi kelembapan dapat memengaruhi transmisi vector borne disease. Vektor nyamuk bersifat sensitif terhadap kelembapan. Kelembapan memengaruhi keberadaan nyamuk karena berhubungan dengan sistem pernafasan nyamuk. Sistem pernafasan nyamuk menggunakan pipa udara (trachea) dengan lubang pada dinding tubuh nyamuk yang disebut spiracle. Spiracle nyamuk berada dalam kondisi terbuka tanpa ada mekanisme untuk mengatur sehingga sensitif terhadap kelembapan di lingkungan. Apabila kelembapan di lingkungan rendah maka penguapan air dari dalam tubuh nyamuk akan membuat nyamuk kekurangan cairan tubuh (Dinata, et al., 2012). Tingkat kelembapan $60 \%$ merupakan batas paling rendah untuk memungkinkan hidupnya nyamuk. Pada kelembapan kurang dari $60 \%$, umur nyamuk akan semakin pendek. Kelembapan udara yang tinggi berkisar $85 \%$ akan memperpanjang umur nyamuk (Herawati, et al., 2014; Pohan, 2014). Umur nyamuk yang semakin panjang akan mengakibatkan frekuensi gigitan nyamuk juga meningkat dan dapat mengakibatkan penularan penyakit DBD semakin tinggi. 


\section{Perilaku Masyarakat}

Uji Chi Square antara variabel perilaku masyarakat dengan kasus DBD menunjukkan bahwa tidak adanya hubungan dinatara kedua variabel tersebut. Tidak adanya hubungan antara perilaku dengan kasus DBD. Hal ini menunjukkan bahwa peningkatan perilaku masyarakat tidak akan diikuti dengan peningkatan kasus DBD di wilayah kerja Puskesmas Putat Jaya (Fitriana, 2017). Dalam penelitian ini perilaku masyarakat yang dianalisis diantara lain adalah perilaku $3 \mathrm{M}$ plus yang meliputi menguras penampungan air, menutup penampungan air, mengubur barang bekas, penggunaan kelambu berinsektisida, penambahan ikan di bak mandi, menaburkan bubuk abate di penampungan air, penggunaan obat nyamuk, menggantung pakaian kotor, dan pemasangan kawat kasa pada ventilasi rumah.

Menurut Depkes RI (2010), pengurasan tempat penampungan air perlu dilakukan secara teratur sekurangkurangnya seminggu sekali agar nyamuk tidak dapat berkembang biak di TPA. Pada saat ini telah dikenal istilah $3 \mathrm{M}$ plus, yaitu kegiatan 3M yang diperluas. Bila Pemberantasan Sarang Nyamuk (PSN) dilaksanakan oleh seluruh masyarakat, maka populasi nyamuk Aedes aegypti dapat ditekan serendah-rendahnya, sehingga penularan DBD tidak terjadi lagi. Hal ini dilakukan berdasarkan pertimbangan bahwa perkembangbiakan siklus hidup nyamuk Aedes $s p$ adalah 9-12 hari. Waktu yang diperlakukan nyamuk untuk berkembang biak menjadi dasar mengapa kegiatan PSN dilakukan seminggu sekali.

Hasil penelitian di atas tidak sejalan dengan penelitian Winarsih (2013) yang memperoleh hasil terdapat hubungan antara perilaku masyarakat dalam membersihkan tempat penampungan air dengan kasus DBD. Penelitian tersebut menunjukkan bahwa orang yang tidak menguras TPA mempunyai risiko 3,780 kali lebih besar menderita DBD daripada responden yang membersihkan TPA.

Penggunaan kelambu merupakan salah satu upaya pencegahan penyakit DBD. Upaya yang dapat melindungi diri dari gigitan nyamuk antara lain dengan menggunakan pakaian pelindung, menggunakan obat nyamuk bakar, repellent, menggunakan kelambu baik yang dicelup larutan insektisida maupun tidak (Depkes, 2005). Pemakaian obat nyamuk bakar atau repellent di siang hari merupakan salah satu upaya pencegahan diri dari penyakit DBD. Memakai obat nyamuk bakar, dan repellent merupakan cara perlindungan diri. Kegiatan menggunakan kelambu berinsektisida, memasang kawat kasa, dan memakai obat nyamuk merupakan upaya untuk mencegah gigitan nyamuk (Depkes, 2005). Melalui pemakaian obat nyamuk di siang hari dapat meminimalisir gigitan nyamuk Aedes aegypti yang merupakan vektor pembawa virus dengue.

\section{Hubungan Faktor Lingkungan dengan Tingkat Endemisitas Kasus DBD}

Hasil penelitian menyatakan bahwa tidak semua faktor lingkungan yang meliputi suhu, curah hujan, dan kelembapan mempunyai hubungan dengan kasus DBD. Hasil penelitian faktor lingkungan yang mempunyai risiko dengan kasus DBD adalah suhu. Faktor suhu dapat meningkatkan kasus DBD di wilayah kerja Puskesmas Putat Jaya dan menyebabkan tingkat endemisitas wilayah tersebut menjadi tinggi atau meningkat. Penelitian di atas didukung oleh penelitian lain yang menunjukkan adanya hubungan antara suhu dengan kasus DBD yang dapat meningkatkan risiko kasus DBD (Arifin, et al., 2013; Prastiani, 2016). Penelitian lain menunjukkan hasil korelasi hubungan suhu dengan kasus DBD memiliki kekuatan hubungan sedang dan arah hubungan positif $(r=0,301)$ sehingga peningkatan suhu akan diikuti peningkatan kasus DBD (Kurniawati, 2016). 
Hasil rata-rata suhu, curah hujan, dan kelembapan selama tahun 2014-2016 mengalami kenaikan rata-rata dari tahun sebelumnya sehingga dapat berisiko menjadi faktor terjadinya peningkatan kasus DBD apabila tidak diimbangi dengan upaya pencegahan yang dilakukan oleh masyarakat. Melihat data kasus DBD dari tahun 2014 ke tahun 2015 terjadi peningkatan dan dari tahun 2015 ke tahun 2016 mengalami pernurunan. Sehingga faktor lingkungan mempunyai risiko peningkatan kasus DBD di tahun yang akan datang.

\section{Hubungan Perilaku Masyarakat dengan Tingkat Endemisitas Kasus DBD}

Hasil penelitian di atas menyatakan bahwa faktor perilaku masyarakat tidak ada hubungan dengan kasus DBD sehingga faktor perilaku masyarakat di wilayah kerja Puskesmas Putat Jaya tidak memengaruhi tingkat endemisitas wilayah tersebut menjadi tinggi akan tetapi wilayah kerja Puskesmas Putat Jaya tingkat endemisitasnya tetap. Penelitian di atas sejalan dengan penelitian lain bahwa tidak ada hubungan antara perilaku masyarakat dengan kasus DBD (Mardiana, 2013; Muchlis, et al., 2011). Berbeda dengan penelitian yang dilakukan Prastiani (2016) menunjukkan bahwa adanya hubungan antara perilaku masyarakat dengan kasus DBD.

Hasil penelitian menunjukkan bahwa kategori perilaku masyarakat di wilayah kerja Puskesmas Putat Jaya adalah kurang dengan skor nilai 1-13 dengan jumlah sebesar 78,6\% untuk kelompok kasus dan kelompok kontrol sebesar $89,3 \%$. Kemungkinan faktor perilaku masyarakat tidak ada hubungan langsung dengan kasus DBD namun faktor perilaku masyarakat tersebut mempunyai pengaruh dalam mendukung terjadinya kasus DBD. Melihat data kasus DBD dari tahun 2014 ke tahun 2015 terjadi peningkatan dan dari tahun 2015 ke tahun 2016 mengalami pernurunan, sehingga mempunyai risiko angka kasus DBD dapat terjadi peningkatan lebih banyak lagi di tahun yang akan datang.

\section{SIMPULAN}

Hasil penelitian menyatakan bahwa tidak semua faktor lingkungan ada hubungan dengan kasus DBD. Hasil penelitian faktor lingkungan yang ada hubungan dengan kasus DBD adalah suhu sehingga mempunyai risiko meningkatkan kasus DBD di wilayah kerja Puskesmas Putat Jaya.

Bagi instansi Puskesmas perlu dilakukan peningkatan kesadaran terhadap warga untuk membiasakan melakukan kegiatan $3 \mathrm{M}$ plus dan perlu adanya kerja sama dengan instansi BMKG untuk memberikan informasi terkait perubahan suhu di wilayah Surabaya. Bagi masyarakat wilayah kerja Puskesmas Putat Jaya Surabaya disarankan pada suhu yang baik dalam perkembangbiakan nyamuk dihimbau untuk memperhatikan lingkungan rumah seperti tidak membiarkan TPA terbuka dan menggantung pakaian kotor yang dapat menjadi tempat perindukan nyamuk. Selain itu masyarakat disarankan untuk menjaga kebersihan lingkungan seperti melakukan upaya pencegahan $3 \mathrm{M}$ plus yang meliputi menguras penampungan air, menutup penampungan air, mengubur barang bekas, penggunaan kelambu berinsektisida, penambahan ikan di bak mandi, menaburkan bubuk abate di penampungan air, penggunaan obat nyamuk, menggantung pakaian kotor, dan pemasangan kawat kasa pada ventilasi rumah sehingga apabila saat musim hujan tiba tidak terjangkit penyakit DBD, mengingat lingkungan wilayah kerja Puskesmas Putat Jaya masih rawan terjangkit DBD. Sebaiknya masyarakat tidak menanamkan sugesti bahwa merawat atau menjaga kebersihkan lingkungan sebagai beban melainkan sebagai hobi agar dalam pelaksanaannya tidak berat. 


\section{DAFTAR PUSTAKA}

Arifin, Asrianti, Erniwati Ibrahim, dan Ruslan La Ane. 2013. Hubungan Faktor Lingkungan dengan Keberadaan Larva Aedes di wilayah Endemis DBD di Kelurahan Kassi-Kassi Kota Makasar 2013. Skripsi. Makasar: FKM Universitas Hassanudin.

BMKG. 2010. Kondisi Cuaca Ekstrem dan Iklim Tahun 2010-2011. Jakarta: Press Release.

Depkes. R.I., 2005. Pencegahan dan Pemberantasan Demam Berdarah Dengue di Indonesia. Jakarta: Ditjen PPM PL.

Depkes, 2010. Buletin Jendela Epidemiologi, Vol. 2, Agustus. Jakarta: Pusat Data dan Surveilans Epidemiologi Kementerian Kesehatan RI.

Dinata, A., dan Dhewantara, P.W., 2012. "Karakteristik Lingkungan Fisik, Biologi, Dan Sosial Di Daerah Endemis DBD Kota Banjar Tahun 2011" dalam Jurnal Ekologi Kesehatan, Vol.11, No. 4, Desember.

Dinas Kesehatan Kota Surabaya, 2015. Profil Kesehatan Kota Surabaya Tahun 2014. Surabaya: Dinas Kesehatan Kota Surabaya.

Dinas Kesehatan Kota Surabaya, 2016. Profil Kesehatan Kota Surabaya Tahun 2015. Surabaya: Dinas Kesehatan Kota Surabaya

Dinas Kesehatan Kota Surabaya, 2017. Profil Kesehatan Kota Surabaya Tahun 2016. Surabaya: Dinas Kesehatan Kota Surabaya

Dinas Kesehatan Provinsi Jawa Timur, 2016. Profil Kesehatan Provinsi Jawa Timur 2015. Surabaya: Dinas Kesehatan Provinsi Jawa Timur

Dini, A., M., V., Fitriany, R., N., dan Wulandari, R. A., 2010. "Faktor Iklim dan Angka Insiden Demam Berdarah Dengue di Kabupaten
Serang" dalam Jurnal Makara, Kesehatan, Vol. 14, No. 1, Juni.

Dirjen PPM, PLP. 2002. Pedoman Teknis Penilaian Rumah Sehat. Jakarta: Depkes RI

Fitriana, B.R., 2017. Hubungan Faktor Lingkungan dengan Tingkat Endemisitas DBD di Puskesmas Putat Jaya Surabaya. Skripsi. Surabaya: Perpustakaan Universitas Airlangga.

Gama, A, dan Betty, F. 2010. Analisis Faktor Risiko Kejadian Demam Berdarah Dengue di Desa Mojosongo Kabupaten Boyolali. Eksplanasi Vol 5 No 2 Edisi Oktober 2010. Surakarta: Fakultas Ilmu Kesehatan Universitas Muhammadiyah.

Gama, Z.P., dan Nakagoshi, N., 2013. Climatic Variability and Dengue Hermaorrhagic Fever incidence in Nganjuk District, East Java, Indonesia.Jurnal Acta Biologica Malaysiana 2(1).

Gyawali, Narayan., Bradburry, Richard, Robinson, Andrew W.T., 2015. Knowledge, Attitude and Recommendations of Pratice Regarding Dengue Among the Resident Population of Queensland Australia. Asian Pasific Journal Tropic Biomed 2016,6 (4).

Herawati, Y., dan Utomo, S.W., 2014. The Dynamics of Population Density and Climate Variability on Dengue Heamoarrhagic Fever (DHF) Incidence in Bogor City, West Java, Indonesia. Research Journal of social Science and Management, Vol.4, No. 4. Agustus.

Ibarra, A.M.S., Ryan S.J., Beltran E., mejia R., Silvia, M., dan Munoz, A., 2013. Dengue Vektor Dynamics (Aedes Aegypti) Influenced by Climate and Social Factors in Ecuador: Implications for Targeted Control. PLOS One Journal, Vol. 8, No. 11, November. 
Jumar. 2000. Entomologi Pertanian. Jakarta: Rineka Cipta.

Kurniawati, N.T., 2016. Distribusi Kejadian DBD, Kondisi Iklim, Kepadatan Jentik dan Program Pengendalian di wilayah kerja Puskesmas Putat Jaya Tahun 20102014. Skripsi. Surabaya: Perpustakaan Universitas Airlangga.

Mardiana, D.S. 2013. Kepadatan Jentik dan Perilaku Masyarakat di Daerah Endemis dan Bebas Kasus DBD di Kecamatan Maospati Kabupaten Magetan. Skripsi. Surabaya: Perpustakaan Universitas Airlangga.

Morin, C.W., Comrie, A.C., dan Ernst, K., 2013. Climate and Dengue Transmission: Evidence and Implications. Enviromental Health Prespective, Vol. 121, No. 11-12, November-Desember.

Muchlis, Sumarni., Ishak, Hasanudin., Ibrahim, Ernawati., 2011. Faktor Risiko Upaya Menghindari Gigitan Nyamuk Terhadap Kejadian DBD di Puskesmas Patingalloang Makasar. Universitas Hasanudin.

Oktivani, M. 2011. Perbedaan Kepadatan Jentik Aedes Aegypti Pada Daerah Endemis, Sporadis, dan Potensial DBD di Wilayah Kerja Puskesmas Demangan Kota Madiun. Skripsi. Surabaya: Perpustakaan Universitas Airlangga.

Prastiani, I. 2016. Hubungan antara Lingkungan Fisik, Kimia, Sosial Budaya dengan Kepadatan Jentik
(Studi di wilayah Kecamatan Gunung Anyar Kota Surabaya. Skripsi. Surabaya: Perpustakaan Universitas Airlangga.

Pohan, Z., 2014. Hubungan Iklim Terhadap Kasus Demam Berdarah Dengue (DBD) di Kota Palembang Tahun 2003-2013. Skripsi. Universitas Sriwijaya.

Sitio, Anton., 2008. Hubungan Perilaku tentang Pemberantasan

SarangNyamuk dan Kebiasaan Keluarga dengan Kejadian DBD di Kecamatan Medan Perjuangan Kota Medan Tahun 2008. Tesis. Universitas Diponegoro Semarang.

Soegijanto, S, 2006. Demam Berdarah Dengue. Surabaya: Airlangga University Press.

Sugito, R. 1989. Aspek Entomologi Demam Berdarah Dengue. Laporan Semiloka. Proceeding Seminar and Workshop The Aspects of Hemoragic Fever ang Its Control.

Suwanbamrung, Charuai., Promsupa, Somjit., Doungsin, Teera., Tongjan, Supapon., 2013. Risk Factor Related to Dengue Infections Inprimary School Students: Exploring Student's Basicknowledge of Dengue and Examining The Larvalindices in Southern Thailand. Journal of Infection and Public Health (2013) 6.

Winarsih, Sri., 2013. Hubungan Kondisi Lingkungan Rumah dan Perilaku PSN dengan Kejadian DBD. Unnes Journal of Public Health, 2(1) 